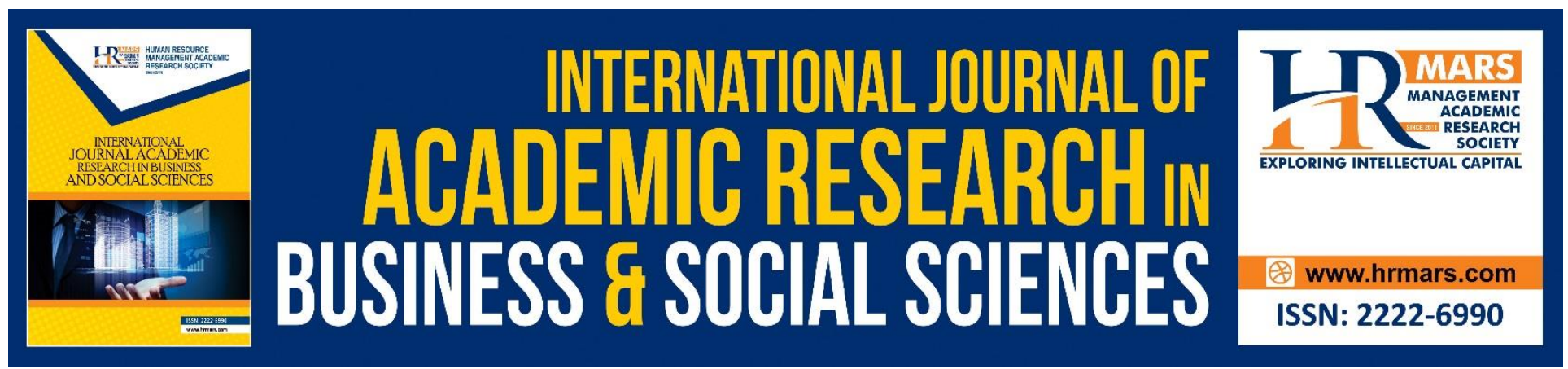

\title{
Conflict of Character and Resolution in Animal Stories
}

\section{Nadiatul Shakinah Abdul Rahman, Salmah Jan Noor Muhammad and Siti Rabiatul Adawiah Jaffar}

To Link this Article: http://dx.doi.org/10.6007/IJARBSS/v8-i8/4613

DOI: $\quad 10.6007 /$ IJARBSS/v8-i8/4613

Received: 13 June 2018, Revised: 19 July 2018, Accepted: 29 July 2018

Published Online: 06 August 2018

In-Text Citation: (Rahman, Muhammad, \& Jaffar, 2018)

To Cite this Article: Rahman, N. S. A., Muhammad, S. J. N., \& Jaffar, S. R. A. (2018). Conflict of Character and Resolution in Animal Stories. International Journal of Academic Research in Business and Social Sciences, 8(8), 572-584.

Copyright: (C) 2018 The Author(s)

Published by Human Resource Management Academic Research Society (www.hrmars.com)

This article is published under the Creative Commons Attribution (CC BY 4.0) license. Anyone may reproduce, distribute, translate and create derivative works of this article (for both commercial and non-commercial purposes), subject to full attribution to the original publication and authors. The full terms of this license may be seen at: http://creativecommons.org/licences/by/4.0/legalcode

Vol. 8, No. 8, August 2018, Pg. 572 - 584

http://hrmars.com/index.php/pages/detail/IJARBSS

JOURNAL HOMEPAGE

Full Terms \& Conditions of access and use can be found at http://hrmars.com/index.php/pages/detail/publication-ethics 


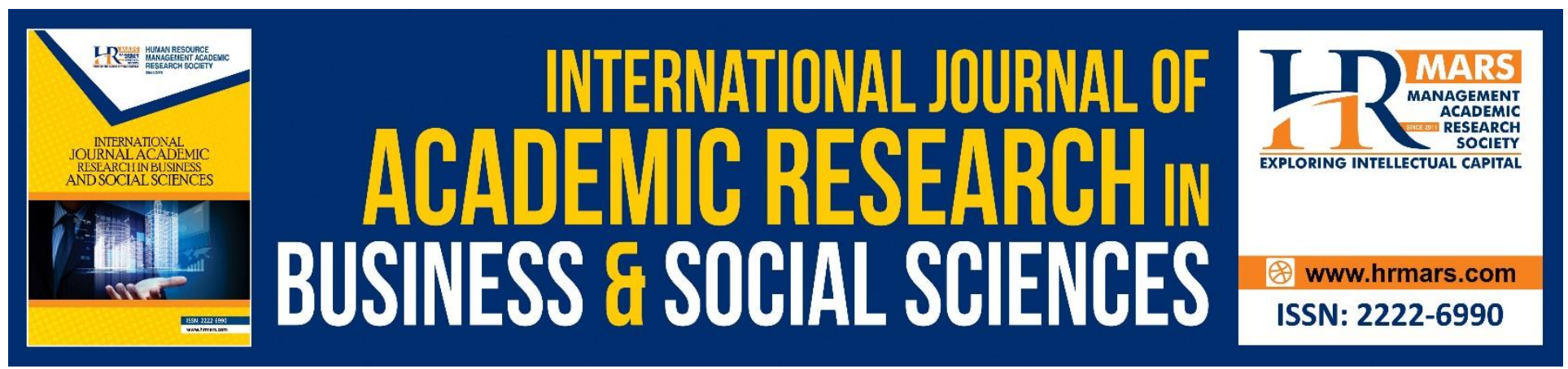

\title{
Conflict of Character and Resolution in Animal Stories
}

\author{
Nadiatul Shakinah Abdul Rahman, Salmah Jan Noor Muhammad \\ and Siti Rabiatul Adawiah Jaffar
}

Faculty of Modern Language and Communication, Universiti Putra Malaysia

\begin{abstract}
Animal stories put forth the animal characters such as Sang Kancil, Sang Harimau, Sang Rusa and Sang Buaya as the characters that lead a life in the forest. Often times, these characters are portrayed as human beings that capable of speaking, thinking, articulating and doing things a human being used to do. Therefore, animal characters are also not escapable from having myriad of conflicts and problems as real human beings do. On the other note, animal stories are prone in displaying intelligent character such as Sang Kancil that has ecumenical ability to resolve problems and conflicts by the employment of diversified tricks to accomplish its goals. This paper will study two main focuses which are identifying and analyzing the applied mechanism by animal characters from Hikayat Sang Kancil and Kumpulan Cerita Sang Kancil as the research data. The methodology of this research employed the qualitative approaches that were library research and research data analysis. The meticulous analysis conducted revealed that an animal character that is Sang Kancil employed the flora and fauna elements as the mechanisms to solve problems and conflicts and the impacts were observable in the positive manner for each problem solved. Hence, humans are benefitted to observe examples and lessons from the animal intelligentsia in resolving conflicts and problems.
\end{abstract}

Keywords: Conflicts, fauna, flora, mechanism, problem-solving, Sang Kancil

\section{Introduction}

Animal stories exhibit a story line that puts forth the animal characters as the main character. The animal characters portrayed hold the human traits and behaviours such as ability to talk, think, articulate, cheat and trick. Animal stories set out the animal characters such as mousedeer, tiger, deer and snake that live in forest. This fact has been propounded by Hamid (1986) saying that animal stories is a verbal form of story, known as mergastua stories that apply animals as the characters in a story and have the ability to talk, articulate and possess rationality like human beings.

On the other note, the storyline of animal stories usually involves conflicts that cause many problems among the animals. Othman and Sulaiman (2008) explained that the conflict is a normal and cannot be avoided and the conflicts happen when a party interacts with one another. Conflicts happen are due to the frictional forces, dissenting opinions, values and behaviours between two characters. This can be clearly seen through the character of Sang Kancil that has conflicts with other animals. 
INTERNATIONAL JOURNAL OF ACADEMIC RESEARCH IN BUSINESS AND SOCIAL SCIENCES

Vol. 8, No. 8, August 2018, E-ISSN: 2222-6990 @ 2018 HRMARS

Moreover, conflict and problem-solving in animal stories also shows the character of Sang Kancil as a smart, intelligent and brilliant one in resolving those conflicts and problems by using diversified strategies, tricks and tactics. Furthermore, Sang Kancil is a small-sized animal that has been portrayed to be able to defeat the bigger-sized animals than it. Ismail Hamid (1986) stated that Sang Kancil or Pelanduk are the main figures in animal stories in which their brilliant characters are depicted as having the intelligent traits and smart as well as capable of defeating the bigger animals even though Sang Kancil and Pelanduk are usually characterized as physically weak. In addition to this, Sang Kancil is described as an animal that used to help other animals around by employing tricks. Sang Kancil makes a good role as a smart animal to play tricks on other animals. Plus, its intelligence is capable of defeating the bigger animals than it. The story of this sort could give lessons that intelligence and wisdom in strategic management holds a weapon to overtake the strong enemies.

Therefore, the creations of the world either humankind or animals are not exception in encountering unexpected problems that need special mechanism and immediate responses for a resolution. This has been projected by Othman and Sulaiman (2008) as every creation will encounter myriad of problems either big or small in nature. At times, the problems are clear cut to be solved but it may come the other way around. The problems faced should be responded with a specific action and resolution. Not to mention, it takes to have proper and specific skills to solve a problem. The knowledge of problem recognition, concept and factor influence the actions taken to a problem.

In relation to this, the presence of conflict or problem can appear in any circumstances, setting and time. Problems arise are due to the specific causes as stated by Othman and Sulaiman (2008) saying that every problem happened must come from a specific cause. They furthered the contention with the fact that the cause of a problem appears from the micro surrounding or macro surrounding. In addition to this, problem can be defined as a situation when there is a gap or change from the desired outcome with the earned outcome, there is an uncertainty emerges, challenges in reaching a specific goal or in making the best choice. Logically speaking, conflict and problem need to be resolved by using the specific mechanism as a resolution.

\section{Literature Review}

Observation made from the past studies by the former researchers has shown some of findings from various aspects. One of them is a research entitled, 'Konflik Emosi dalam Lirik Lagu Nipah oh Nipah' by Rahim and Roslan in 2017. The research used the total of 20 students of sample as the respondents through interview to see the aspect of communicative emotion towards the lyric of the song. The finding of the research showed that emotions associated in the song were sad, angry and happy. It is clearly to say that this research focused on emotional conflict that lies in the lyrics of the song.

Furthermore, the study of conflict was also carried out by Shafie in 2015 with a study entitled 'Konflik Komunikasi Dari "Bercak" ke Menongkah Lumrah karya Azmah Nordin.' The study was seen from the aspect of conflict of communication. Shafie (2015) in her study touched on the authorship of Azmah Nordin in the work that produced the short story "Bercak" and the idea in the short story was later developed in the novel Menongkah Lumrah. According to her, Azmah Nordin highlighted the conflict of human reality in the world of digital entrepreneurship. In fact, the author's creativity is revealed through paintings of human nature that experience conflict as illustrated in her work. In addition, Rusli also conducted a study entitled "Konflik Kejiwaan dalam novel Interlok Karta Abdullah Hussin" in 2015. The study was based on the character of Maniam who was a study sample in showing psychological conflict by using the approach of Psychoanalysis Sigmund Freud, Humanistic Abraham 
INTERNATIONAL JOURNAL OF ACADEMIC RESEARCH IN BUSINESS AND SOCIAL SCIENCES Vol. 8, No. 8, August 2018, E-ISSN: 2222-6990 @ 2018 HRMARS

Maslow and Islamic Psychology. The study found that the mental conflict experienced by the character of Maniam was caused by economic and social factors that he has responded based on his subconscious mind until he developed the id within him and the ego attuned his role in resolving the problem. Indeed, this study clearly focuses on Maniam's psychological conflict in the Interlok novel by using the psychoanalytic approach of Sigmund Freud.

A study by Din and Affendi namely ' Unsur Konflik dalam Novel Remaja Terpilih' in 2016 touched on the element of conflict contained in the teen novels such as Azfa Hanani, 6:20 and Merenang Gelora which was shown through Abraham Maslow's Humanistic theory. The study showed that the conflict in the novel was seen from the aspect of youth conflict with family, self and peer group. As a whole, the study found that youth conflict with peers showed the dominant conflict faced by adolescents. In fact, Din and Affendi (2016) also explained that conflict is something normal and teenagers need to handle the conflict wisely.

Based on these studies, it was found that studies on conflict are only seen through human nature; in fact, animal characters also experience the conflicts like those experienced by humans. Due to this, this paper will examine the aspects of conflict that revolves in the nature of animals. The conflict faced needs to be handled wisely and creatively. This has been stated by Tak (1995) that in solving a problem and conflict, it requires creativity. This is because creativity is powerful in sparking imagination and thought in producing something new, creative and useful. She conceptualized that creativity is the resolution of conflicts and problems. In fact, creative result doesn't come in serendipity and the results bear the values of aesthetic, quality and effective.

In addition, Othman and Sulaiman (2008) argued that the key failure in problem-solving is due to the lack of knowledge and skills in the techniques and processes involved in solving the problems. Indeed, proficiency in solving problems is seen to be vital and needs to be improved and act rationally, logically and creatively. In fact, the ability to think creatively and critically is said to be able to produce creative and innovative ideas.

Such statement can be seen indirectly in animal stories through the brilliant, intelligent and smart Sang Kancil that used creative mechanisms of deception or tricks in handling the problems. Past studies found no studies on animal stories that focus on conflict resolution mechanisms and problems. Studies on animal stories have been traced from other aspects such as those conducted by Rosly, Rahim and Halim in 2015 entitled "Pengaruh Elemen Cerita Binatang Berbentuk Digital ke atas Ujaran Kanak-kanak Sindrom Asperger." The research used animal stories of Sang Singa and Sang Tikus in virtual form as the researched subject matter in nurturing the communitive interaction for Asperger's syndrome children by using Theory of Mind (ToM) and Theory of Discourse Analysis. Research finding found that virtual animal stories are indirectly catalyzing the communicative interaction among Asperger's syndrome children.

Research pertaining to animal stories is also ventured by Saad, Kamaruzzaman and Samah in year 2009 entitled, "Fungsi Cerita Binatang dalam Sastera Kanak-kanak Melayu-Arab". The research used animal stories as the source of research data that showed comparison between Malay and Arab animal stories. The focus of discussion were prone to the characters of animal, theme, pattern and function in animal stories. It is clearly seen to assert that the researches on animal stories haven't really touched on problem and conflict resolution mechanism.

Next, the research with title "Mekanisma Penyelesaian Masalah dalam Hikayat Sang Kancil" by Muhammad and Rahman in year 2018. This research focus on resolving problems mechanism that Sang Kancil used to help other animals and itself when they confront with the biggest animals and predator like Sang Harimau and Sang Bedal. Sang Kancil is a small animal but have a good thinking 
INTERNATIONAL JOURNAL OF ACADEMIC RESEARCH IN BUSINESS AND SOCIAL SCIENCES Vol. 8, No. 8, August 2018, E-ISSN: 2222-6990 @ 2018 HRMARS

and great idea to trick the biggest animal and resolve the problems. The research by Muhammad and Rahman (2018) focuses on resolving problems mechanism using a flora such as tree truck, tree skin, bamboo and fauna such as fly, bluebottle fly, python and crocodile to solve the problems for other animals and itself. It is clearly different to this research because this research only focus on resolving conflict mechanism that Sang Kancil uses when confront with conflict between Sang Kancil and biggest and strong animals like Sang Harimau, Sang Bedal and Sang Gajah.

Therefore, in addressing problem or conflict, there must be ways for its resolution, action or mechanism. This paper will give a focal attention into two main objectives which are identifying and analyzing the mechanism used by Sang Kancil in Hikayat Sang Kancil and Kumpulan Cerita Sang as a research material by studying its text contents as research data.

\section{Research Methodology}

This paper used the qualitative approach through library research in collecting necessary data and related references. The selected data was chosen and disseminated. Then, the collected data was analyzed for the preparation of conclusion. Data analysis was conducted by considering the process of problem-solving as showed in Figure 1:

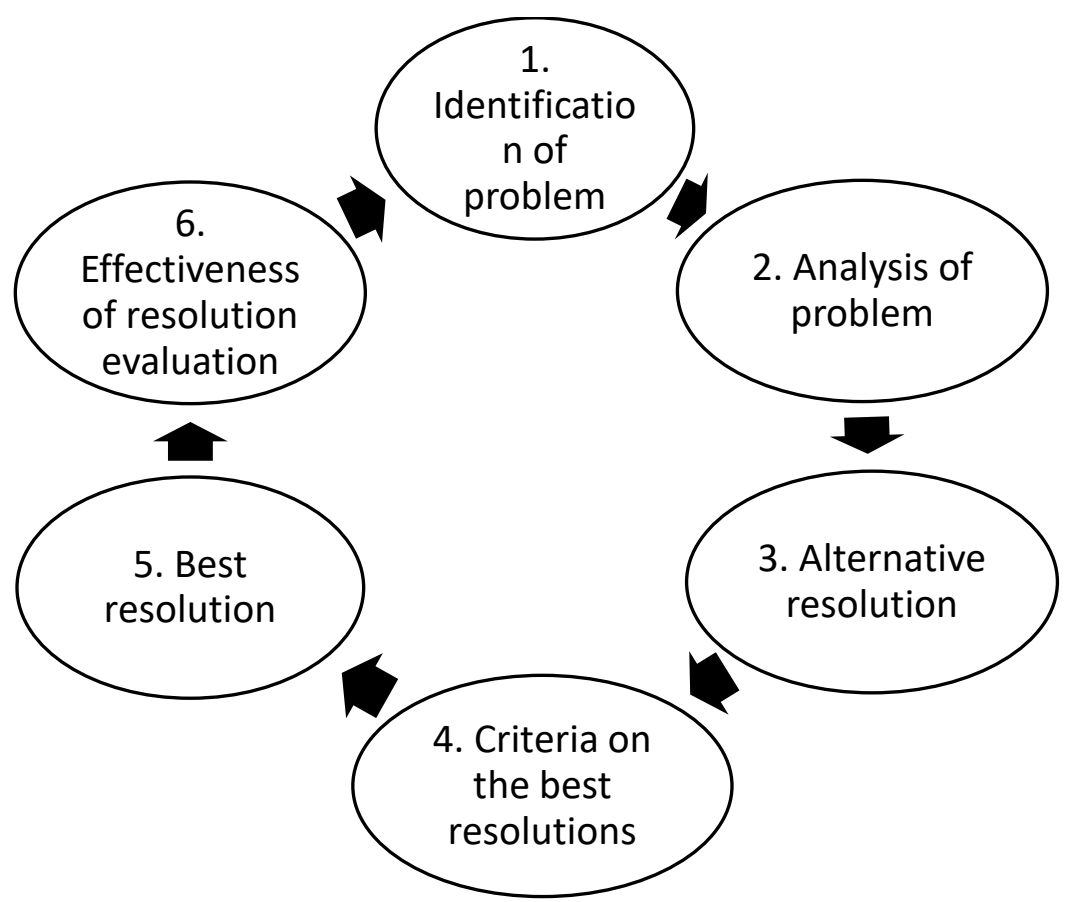

Figure 1. Problem-Solving Process (Stevens, 1996)

\section{Research Findings and Discussion}

The focus of this paper is to see the aspect of conflict that happened between the characters of Sang Kancil with other animals. The resolution of conflicts and problems encountered by Sang Kancil were addressed by the employment of flora and fauna element as a mechanism that was conflict-solving approach as portrayed in Hikayat Sang Kancil and Kumpulan Cerita Sang Kancil.

\section{Flora}


INTERNATIONAL JOURNAL OF ACADEMIC RESEARCH IN BUSINESS AND SOCIAL SCIENCES

Vol. 8, No. 8, August 2018, E-ISSN: 2222-6990 @ 2018 HRMARS

The word flora comes from Latin word which means goddess of flower and garden protector and goddess of fertility in Roman mythology. Herbs are classified as flora. Merriam-Webster's Collegiate Dictionary (2003) explained that these plants live in an area, place or at an age or period. Plants are grouped into flora, depending on the region, age, or typical environment. The area is a different habitat in terms of geography, for example mountains are comparable to land. This is as stated by Yong (1990) that plants can be seen from various types of low plants such as toadstools and algae, flowerless seed plants such as coniferous and flowering plants such as mangrove, reed, sap and so on. In Hikayat Sang Kancil and Kumpulan Cerita Sang Kancil, the character of Sang Kancil used flora as a mechanism in solving the problem or conflict he faces. Among the plants used are bamboo and wooden stump.

\section{Bamboo}

Bamboo is a kind of plant that grows rapidly. Bamboo is hard, grows tall and lives in a group. Chan (2003) and Yong (1990) stated that bamboo is green, yellow and black that easily grow over 30 meters. In addition, Merriam-Webster's Collegiate Dictionary (2003) stated that bamboos are woody grasses that live in tropical and medium temperature regions that have hollow stems, thick rhizomes and shoots that are used for food. Likewise, these characteristics make bamboo is used in making furniture, buildings and tools. Ibrahim and Khamis (2009) also explained that bamboo shoots can be used as vegetables in various types of cuisine. Reed shrubs are used as decorative items or hairstyles and sometimes used in the medical field to treat diseases such as black magic or poison and the leaves are used as food packages. In fact, bamboos are also used in paintings, poetry, hand bars, musical instruments, fishing rods, staples or food staples, and raw materials for daily use such as baskets, hats and used clothes (Chan, 2003; Yong, 1990; and Husin 2008).

The use of bamboo as a mechanism to resolve the conflict between Sang Kancil and Sang Harimau (Pak Belang) and Sang Bedal. The resolution can be seen as a text passage below:

Sang Kancil sedang mencangkung dekat serumpun buluh. Harimau pun berseru, 'Hai Kancil bedebah, kali ini matilah engkau ku makan!'

la berkata 'Hai Sang Pahlawan, sabarlah dulu! Aku tak akan ke mana-mana lagi kerana aku disuruh oleh Tuanku Raja Sulaiman menjaga benda ini.'

Ujar Sang Harimau, 'Apa yang engkau tunggu di sini?'

'Tidakkah engkau lihat benda di hadapan engkau itu?' tanya Sang Kancil pula. 'Inilah yang aku tunggu biola Raja Sulaiman.

Sekarang ku terangkan cara-cara menggeseknya. Kau harus menggeseknya dengan lidah.

Buluh itu segera digeseknya dengan lidahnya. Kebetulan pula masa itu angin sedang bertiup kencang. Maka tersepitlah lidah harimau. la menjerit kerana terlalu sakit. (Hikayat Sang Kancil, 1976:16-17)

[Sang Kancil was squatting a near bamboo cob. Tiger exclaims, 'Hey mouse deer, this time I will eat you and you will die!'

He said 'Hey Sang Pahlawan, be patient first!' I will not go anywhere because King Solomon asked me to take care this thing.

Sang Harimau saying, 'What have you waiting here?'

'Can't you see the thing in front of you?' ask Sang Kancil.

'I am waiting King Solomon violin.' 
INTERNATIONAL JOURNAL OF ACADEMIC RESEARCH IN BUSINESS AND SOCIAL SCIENCES

Vol. 8, No. 8, August 2018, E-ISSN: 2222-6990 @ 2018 HRMARS

Now I will explain how to swiping this. You should swipe this with your tongue.

He swiped the bamboo with his tongue. Accidently, that time the wind blowing. Tiger tongue was pinched. He shouted because he indeed sick.]

(Hikayat Sang Kancil, 1976:16-17)

Sang Kancil was always in conflict with Sang Harimau because Sang Kancil used to cheat the Sang Harimau. Consequently, Sang Harimau wanted to take grudge on Sang Kancil by aiming Sang Kancil as its food (prey). Sang Kancil wanted to escape itself from being a prey to Sang Harimau, thus Sang Kancil got the idea to trick Sang Harimau. Sang Kancil used flora elements as a problem-solving mechanism. In this regard, Chan (2003) stated that the bamboo hamlet is a peaceful and cool place with a gentle breeze. Therefore, Sang Kancil got the idea of using a bamboo piece that was symbolized as a violin owned by King Solomon because of the noise caused by the wind. The violin needs a bunch of sticks named as violin bow to play and emit the sound from the instrument. Sang Kancil has tricked Sang Harimau by stating that the violin should be swirled in the tongue. Consequently, Sang Harimau who believed in Sang Kancil's words swiped the bamboo (violin) by using his tongue. This caused his tongue stuck between the bamboos. Sang Kancil's trick was a wise move to escape from Sang Harimau. This signifies that Sang Kancil was creative in solving the problem. Ainon and Abdullah (1994) state that problems can be solved by thinking as shown by the character of the Sang Kancil. In another story, Sang Kancil also used bamboo as a problem-solving mechanism with Sang Bedal as follows:

Sang Kancil sangat terkejut bila disedarinya kakinya telah ditangkap buaya. Setelah berfikir sejurus ia pun berkata, 'Hai Buaya, yang engkau tangkap itu bukan kaki aku, itu buluh. Inilah kakiku yang sebenarnya.' Sambil ia menggoyang-goyangkan sebatang ranting buluh yang menjuntai ke dalam sungai itu. Apabila buaya melihat ranting buluh itu, ia pun melepaskan kaki Sang Kancil. Ditangkapnya pula ranting buluh itu.

(Hikayat Sang Kancil, 1976:26)

[Sang Kancil was shocked when he realizes that his leg was caught by crocodile. He was thinking and he said, 'Hey, crocodile, you was caught the bamboo not my leg. This is my real leg. ' He shook the bamboo branches that dangling from river. When crocodile saw that bamboo branches, it unbend Sang Kancil leg. He caught the bamboo

(Hikayat Sang Kancil, 1976:26)

branch.]

The study of this passage shows that Sang Kancil had used the bamboo as a problem solving mechanism to escape from Sang Bedal (crocodile) which has bitten the Sang Kancil's feet. Consequently, the use of the bamboo branches was the symbolic to the Sang Kancil's leg that has been gripped by Sang Bedal. The use of bamboo branches was appropriate because the size of the bamboo branches was almost the same as the size of Sang Kancil's leg. The situation shows the wisdom of the Sang Kancil in manipulating the situation, thus making the Sang Bedal believed and released the Sang Kancil's feet. Although Sang Bedal was a huge and savage animal, Sang Kancil managed to escape from being a victim by using its wisdom and creativity. This situation indirectly describes the Creator's Creativity in resolving the conflict. As described by Ainon and Abdullah (1994), the uses of tricks is a new idea of solving the problem creatively. 
INTERNATIONAL JOURNAL OF ACADEMIC RESEARCH IN BUSINESS AND SOCIAL SCIENCES

Vol. 8, No. 8, August 2018, E-ISSN: 2222-6990 @ 2018 HRMARS

\section{Wooden Stump}

Trees are the necessity for humans and animals to survive because the trees supply oxygen to all the creations of the world. Russell (2012) argued that tree is a necessity for all living things. The tree absorbs carbon dioxide and replaces it with oxygen. Trees are divided into parts such as tree trunks, bark, branches, twigs, leaves, roots, flowers and seeds that have their specific functions. In addition, tree trunks and branches play an important role in absorbing water from tree roots to leaves and moving foods throughout the tree for survival (Thomas, 2014). When a tree is cut down, it will leave the wooden stump because the roots of the tree are still planted. Mitchell and Von der Gonna (1994) stated that the wooden stumps are unnecessary branches and left in an area to provide nutrients for a long period of time. In fact, the size and the wooden stump vary according to the species and the age of the tree that is affected by the type of soil (Wilson, 1981). Therefore, Sang Kancil used a wooden stump as a conflict resolution mechanism with the Sang Gajah as illustrated in the following passages:

Dalam pada itu Sang Kancil telah melihat ada sebuah tunggul kayu besar tidak jauh dari situ. Dia mahu menggunakan tunggul itu dalam pertandingan itu nanti.

"Apa lagi yang ditunggu wahai Sang Gajah yang gagah! Marilah!" ajak Sang Kancil lalu menghampiri tunggul kayu tersebut.

Tanpa membuang masa Sang Gajah pun menyepak betis Sang Kancil. Malangnya, bukan kaki Sang Kancil yang disepaknya tetapi tunggul kayu. Dahi Sang Gajah berkerut menahan sakit. Namun dia tidak berputus asa dan hendak menyepak sekali lagi.

"Sekarang giliran hamba pula menyepak betis tuan hamba," kata Sang Kancil. Sang Gajah tetap menghulurkan kakinya walaupun tidak bermaya.

Apabila Sang Kancil menyepak untuk kali kedua, Sang Gajah menjerit sekuat-kuat hati. Air matanya meleleh-leleh.

"Aduh, tolong hentikan, Sang Kancil," kata Sang Gajah.

(Kumpulan Cerita Sang Kancil, 1992:58-60)

[In that time, not far away Sang Kancil was seeing wooden stump. He wants used that stumps in that match.

'What had you're waiting Sang Gajah! Come on!' Sang Kancil invites him and approach that stump.

Without wasting time, Sang Gajah kicks Sang Kancil calf.

Unfortunately, it is not Sang Kancil calf that Sang Gajah kicked but wooden stump. Sang Gajah forehead was crinkling because he endures pain. Even though, he not gives up and want to kick again.

'Now, my turn to kick your calf,' said Sang Kancil.

Sang Gajah handed over his leg although he weak.

When Sang Kancil kicks for second time, Sang Kancil shout with all one strength. His tears are thawing.

'Oh, please stop, Sang Kancil,' said Sang Gajah.]

(Kumpulan Cerita Sang Kancil, 1992:58-60)

The study of the passage found that Sang Kancil used the flora element of wood stump as a conflict resolution mechanism. The use of the stump was used for a soccer game with Sang Gajah to prove their strength. The match was held because the Sang Gajah and some other animals were envy and angry with the Sang Kancil. In fact, the match was aimed at embarrassing the Sang Kancil, which 
INTERNATIONAL JOURNAL OF ACADEMIC RESEARCH IN BUSINESS AND SOCIAL SCIENCES

Vol. 8, No. 8, August 2018, E-ISSN: 2222-6990 @ 2018 HRMARS

would have been defeated because of its small size being compared to the large size of Sang Gajah. However, Sang Kancil was aware of himself who cannot afford to fight with bigger beats and even won the game. As such, Sang Kancil used some tactics and tricks to win the fight and resolved the conflict between the Sang Gajah and it. The use of the stumps is a symbolic of Sang Kancil's calf. In order to win the game, Sang Kancil hid his calf behind the wooden stump. The Sang Kancil did not realize the situation then it kicked the tree stump so that Sang Gajah endured the pain that can make Sang Gajah to surrender and eventually Sang Kancil won the game. It is clear that the use of wooden stump as a conflict resolution mechanism proves that Sang Kancil is a wise animal that has successfully resolved the conflict. In this case, Ainon and Abdullah (1994) stated that creativity is symbolizes intelligence like character of Sang Kancil in animal stories who resolves conflicts creatively.

\section{Fauna}

The word fauna comes from Latin word which means animal kingdom. This means that the fauna are grouped as animals. Merriam-Webster's Collegiate Dictionary (2003) mentions that fauna are animals especially those that are characterized based on place, district, age or specific environment. Rahim and Banderan (2017) explained that fauna groups are divided into two types, namely, fauna groups and aquatic fauna groups. The main fauna groups are insects, snakes, primates and birds whereas the aquatic fauna group consists of two species, which live in aquatic areas such as fish and shrimp and live in mud like shellfish, crabs and other invertebrate animals. The use of fauna elements as a problem-solving mechanism as found in the Hikayat Sang Kancil and the Kumpulan Cerita Sang Kancil are python and hornet nest.

\section{Python}

Python is categorized as a reptile. Reptilian is cold-blooded animal and capable of transforming itself according to its surrounding habitat especially when there is threat from enemies (Ibrahim and Khamis, 2009). In addition, reptiles can be found worldwide from the dry desert areas, downtown, up to hundreds of meters deep. However, reptiles are not found in the polar and mountain peaks. Due to cold-blooded reptiles, they cannot control their body temperature. Reptile animals have a scaly or rectangular skin consisting of bony or knotted, short legs or have no leg feet. Usually a python sneaks in the jungle and acts as a victim of its prey (Chinery, 2004). In the Hikayat Sang Kancil, the character of Sang Kancil also used the fauna element of the python as a conflict resolution mechanism. This can be seen in the following text excerpt:

Kira-kira dua pelaungan jaraknya, ia pun bertemu dengan seekor ular sawa cindai yang sedang tidur. Ular itu berlingkar-lingkar seperti busut jantan. Sang Kancil pun duduk mencangkung di situ menjaga ular tersebut.

Sang Harimau berkata, 'Apa dia benda yang bertimbun seperti busut ini, Sang Kancil? Dan mengapa engkau menunggunya?'

Jawab Sang Kancil, 'Bodoh benar engkau ini. Tak kau tahu benda ini? Inilah tali bengkung Raja Sulaiman. Tali ini dipakainya tatkala baginda ditabalkan menjadi raja dulu.'

Sang Harimau ingin mencuba dan apabila mendengar seruan itu harimau pun segeralah mengambil ular itu dan melilitnya ke pinggangnya. Baru saja ia melilit dua setengah lilitan, ular itu pun tersedar dari tidurnya. Apabila dirasanya ada benda dalam lilitannya, ia pun segera membelitkannya dengan sekuat-kuatnya. 
INTERNATIONAL JOURNAL OF ACADEMIC RESEARCH IN BUSINESS AND SOCIAL SCIENCES Vol. 8, No. 8, August 2018, E-ISSN: 2222-6990 @ 2018 HRMARS

(Hikayat Sang Kancil, 1976:19-22)

[About two feet, it was meeting a sleeping python. That python was coil like small sharp ant-hill. Sang Kancil was squatting there and care that python. Said Sang Harimau, 'What a thing that cumulative like ant hill, Sang Kancil? And why you're waiting for?'

Sang Kancil was answered, 'You are stupid. Don't know about this thing? This King Solomon belt. He wears this rope in coronation ceremony to be a king.'

Sang Harimau wants to try and when he hear that exclamation, the tiger instantly takes that python and twisting to his waist. After two and half twist, that python is awake. When he feels something in his twist, he promptly binds strongly.] (Hikayat Sang Kancil, 1976:19-22)

The conflict between Sang Kancil and the Sang Harimau was due to the Sang Harimau's resentment against the Sang Kancil. The situation has triggered the Sang Kancil to find tricks to escape from the Sang Harimau. The Sang Kancil, who is described as a clever little one was not afraid when dealing with larger and abusive animals such as Sang Harimau. To escape from Sang Harimau, Sang Kancil had created tricks by using the python as a mechanism of conflict resolution by saying that the python was the belt that belongs to the King Solomon. Sang Harimau who was often been cheated by the Kancil still wanted to try it out. Therefore, when the Sang Harimau was so excited to try the belt, it caused the python to wake up and twist the Sang Harimau around. The situation occurred because the python felt threatened and it later responded by attacking its enemy by twisting the limbs. Thus, Sang Kancil has successfully demonstrated its intelligence to escape from Sang Harimau by using the python. In fact, such actions are spontaneous actions as Makshin (2007) said that individuals who have a creative thinking are able to spontaneously produce a great ideas.

\section{Hornets' nest}

Hornet is a dangerous insect and it has a sting that can kill humans and other animals. The poisons it has will cause inflammation and be able to stop the operation of victim's heart through its sting. Usually, hornet will build its nest on the twigs of a tree. Hornet will attack humans and other animals if their nests are spoiled. In this regard, Said (2013) explains hornets live within its group of venomous insects. Its toxic sting can kill its prey. If we strike the hornets' nest means we are accidentally looking for danger. It is exactly happening to Pak Belang (the Tiger) as a result of his actions. This can be demonstrated through text quotes as illustrated below:

Dia tersenyum melihat sarang tebuan yang tergantung pada dahan pokok di atas kepalanya.

"Eh? Apa tu?" Pak Belang bertanya ingin tahu.

"Kalau Pak Belang nak tahu, itulah gong Raja Sulaiman. Tapi sayang. Tiada seekor haiwan pun di dalam hutan ini yang dibenarkan memukul gong ini.

"Tapi, hamba ingin memukulnya. Bolehkah Sang Kancil?" tanya Pak Belang.

"Pak Belang, boleh pukul gong, Raja Sulaiman mengizinkan!"

Pak Belang pun memukul sarang tebuan itu sekuat hati. Apa lagi bertempiaranlah tebuan-tebuan itu kerana sarangnya sudah pecah. Tebuan-tebuan itu sangat marah lalu mereka menyerang Pak Belang.

(Kumpulan Cerita Sang Kancil, 1992:18-20) 
INTERNATIONAL JOURNAL OF ACADEMIC RESEARCH IN BUSINESS AND SOCIAL SCIENCES

Vol. 8, No. 8, August 2018, E-ISSN: 2222-6990 @ 2018 HRMARS

[He smiles when seeing hornet nest that hanging on tree branches of his head.

'What's that?' Pak Belang asks to know.

'If Pak Belang wants to know, that is King Solomon gong. But its pity. Nobody in this forest can hit this gong.'

'But, I want hit it. Sang Kancil can I hit it?' ask Pak Belang.

'Pak Belang, you can hit it. King Solomon gives the permission!'

Pak Belang hitting strongly the hornet nest. That hornet was scattered because the broken nest. That hornet was angry and attack the Pak Belang.]

(Kumpulan Cerita Sang Kancil, 1992:18-20)

Observation upon the above excerpt found that Sang Kancil was once again encountering a conflict with Pak Belalang (Sang Harimau). Sang Kancil who wanted to escape from being the prey to Pak Belalang (Sang Harimau) had used the hornet's nest as the mechanism to solve its problem. The use of fauna element which was hornet's nest was a symbolic to the gong owned by King Solomon. Pak Belalang (Sang Harimau) who was cheated by the tricks of Sang Kancil had hit the hornet's nest that he thought was a gong. Its action (Sang Harimau) has caused the hornets to attack him. The action was in line with Malay adage, 'sarang tebuan jangan dijolok' that means do not spoil the hazardous things to its finest. In fact, that Sang Kancil actions is a new method in resolving problems like Ainon and Abdullah (1994) said.

\section{Conclusion}

In conclusion, the use of flora elements such as bamboo, wooden stumps and fauna such as snake and hornet's nest as a mechanism of problem-solving did work on the problems encountered by Sang Kancil. The character of Sang Kancil has played a great and vital role in resolving problems it faced. The employment of natural elements such as flora and fauna is relevant and compatible with a life revolving the forest setting. In addition, the use of natural element of flora and fauna as a mechanism of problem-solving is absolutely accurate and comes to fruition in prospering benefits and good to the character of Sang Kancil that encountered those conflicts.

\section{Corresponding Author}

Nadiatul Shakinah binti Abdul Rahman,

Department of Malay Language,

Faculty Modern Language and Communication,

Universiti Putra Malaysia,

Email: shakinahrahman@gmail.com

\section{References}

Chan, E. (2003). Tropical Plants. Singapore: Periplus Editions (HK) Ltd.

Din, F. A. B. C \& Affendi, N. R. N. M. (2016). Unsur Konflik dalam Novel Remaja Terpilih. Jurnal Pendidikan Bahasa Melayu. 6(1), 52-63.

Hamid, I. (1986). Sastera Rakyat Suatu Warisan. Petaling Jaya: Penerbit Fajar Bakti Sdn. Bhd. 
INTERNATIONAL JOURNAL OF ACADEMIC RESEARCH IN BUSINESS AND SOCIAL SCIENCES

Vol. 8, No. 8, August 2018, E-ISSN: 2222-6990 @ 2018 HRMARS

Hassan, H. (2008). Taman Botanikal Melaka: Dunia Hijau Damai \& Ilmu. Ayer Keroh: Perbadanan Hang Tuah Jaya.

Hassan, H. (2008). Spesies Tumbuhan Taman Botanikal Melaka. Ayer Keroh: Perbadanan Hang Tuah Jaya.

Hikayat Sang Kancil. (1976). Petaling Jaya: Penerbit Fajar Bakti Sdn. Bhd.

Ibrahim, T. M. T. dan Khamis, S. (2009). Kepelbagaian Biologi Flora, Fauna dan Nilai Ekonomi Hutan Rimba Tranum, Pahang. Kuala Lumpur: Jabatan Perhutanan Semenanjung Malaysia.

Kumpulan Cerita Sang Kancil. (1992). Kuala Lumpur: Dewan Bahasa dan Pustaka.

Makhsin, M. (2007). Sains Pemikiran dan Etika. Kuala Lumpur: PTS Professional Publishing Sdn. Bhd.

Merriam-Webster's Collegiate Dictionary. (2003). Massachusetts: Merriam-Webster.

Mitchell, J. L and Von der Gonna, M. A. (1994). At The Stump and Roadside Log Processing: Costs and Impacts of Harvesting and Forest Renewal. Canada: Forest Engineering Research Institute of Canada.

Muhammad, S. J. N \& Rahman, N. S. A (2018). Mekanisme Penyelesaian Masalah dalam Hikayat Sang Kancil. In. Affendi, N. R. N. M. et. al. Prosiding Seminar Kanak-Kanak. Kuala Lumpur: Dewan Bahasa dan Pustaka.

Othman, M. \& Sulaiman, H. (2008). Penyelesaian Masalah Teknik dan Aplikasi. Serdang: Penerbit Universiti Putra Malaysia.

Rahim, N. A., Roslan, S. N. A. \& Roslan, N. M. (2017). Konflik Emosi dalam Lirik Lagu 'Nipah oh Nipah.' Jurnal Mahawangsa. 4(1), 89-98.

Rahim, S. \& Baderan, D. W. K. (2017). Hutan Mangrove dan Pemanfaatannya. Yogyakarta; Penerbit Deepublish.

Rosly, N. S., Rahim, N. A. \& Halim, H. A. (2015). Pengaruh Elemen Cerita Binatang Berbentuk Digital ke atas Ujaran Kanak-kanak Sindrom Asperger. 2, 75-85.

Rusli, N. F. M. (2015). Konflik Kejiwaan dalam Novel Interlok Karya Abdullah Hussain (1996). International Journal of the Malay World and Civilisation (IMAN). 3(1), 59-66.

Russell, T. (2012). Trees. London: Dorling Kindersley Limited.

Saad, N. M., Kamaruzaman, K. \& Samah, R. (2009). Fungsi Cerita Binatang dalam Sastera Kanak-kanak Melayu-Arab. In Proceeding of Language and Culture: Creating and Fostering Global Community. Bangi: Universiti Kebangsaan Malaysia. 
INTERNATIONAL JOURNAL OF ACADEMIC RESEARCH IN BUSINESS AND SOCIAL SCIENCES

Vol. 8, No. 8, August 2018, E-ISSN: 2222-6990 C 2018 HRMARS

Said, S. H. (2013). Kamus Peribahasa Melayu. Johor Bahru: Pelangi ePublishing Sdn. Bhd.

Shafie, M. (2015). Konflik Komunikasi dari 'Bercak' ke Menongkah Lumrah Karya Azmah Nordin. Jurnal Komunikasi. 31(2), 169-182.

Stevens, M. (1996). How to Be a Better Problem Solver. London: Kogan Page Limited.

Tak, J. (1995). Penyelesaian Masalah dan Pemikiran Kreatif dalam Pendidikan. Kuala Lumpur: Dewan Bahasa dan Pustaka.

Thomas, P. E. (2014). Trees: Their Natural History. United Kingdom: Cambridge University Press.

Wilson, K.W. (1981). Removal of Tree Stumps. London: Linneys of Mansfield Ltd.

Yahya. H. (2004). Keajaiban Flora dan Fauna Jilid 9. Trans. Sriherwanto, Catur. et. al. Bandung: Dzikra.

Yong, H. S. (1990). Magnificient Plant. Kuala Lumpur: Tropical Press Sdn. Bhd. 